www.globaljournalseries.com, Email: info@globaljournalseries.com

\title{
FACTORS ASSOCIATED WITH MALNUTRITION AMONG UNDER- FIVE CHILDREN IN DEVELOPING COUNTRIES: A REVIEW
}

\author{
R. E. KALU AND K. D. ETIM
}

(Received 7 December 2017; Revision Accepted 25 January 2018)

\begin{abstract}
Malnutrition is a consequence of consumption of dietary nutrient either insufficiently or exclusively by especially children. The aim of this study was to carry out a review of malnutrition-dependent factors among under-five children in developing countries. The study was carried out by reviewing publications on researches on malnutrition conducted in Africa and Asia with particular reference to factors associated with malnutrition. It was found that, of the 162 million children under five years who were stunted, $36 \%$ of them resided in Africa while $56 \%$ were found in Asia. It was also observed that an estimated 60 million under-five children in developing countries were found to be stunted out of which 11 million were Nigerian children. The severity of childhood malnutrition was observed to steadily increase from $11 \%$ in 2003 to $18 \%$ in 2013 for wasting; $24 \%$ in 2003 to $29 \%$ in 2013 for underweight, although there was a decline from $42 \%$ in 2003 to $37 \%$ in 2013 for stunted children. It was observed that high rates of mortality of malnourished children in Sub-saharan Africa result from factors such as low intake of calories, high rates of Human Immuno Virus/Acquired Immunodeficiency Syndrome (HIV/AIDS), political instability, conflicts among groups and poor implementation of government policies. For instance, $50 \%$ mortality of malnourished children in Malawi, Burundi and Madagascar were stunted as a result of poor dietary intake or poor consumption of vital nutrient. Other major factors observed were poverty, absence of exclusive breastfeeding, maternal factors such as poor nutrition during pregnancy, lack of appropriate weight gain, poor consumption of vitamin supplement, illness, environmental factors, and socioeconomic/household factors, all of which affect the nutritional status of children. In conclusion, governments of developing countries and the global community should work together to remove these factors.
\end{abstract}

KEYWORDS: Malnutrition, under-five children, factors, illiteracy, poverty.

\section{INTRODUCTION}

Nutrition is directly or indirectly linked to the seventeen Sustainable Development Goals (SDG) (National Population Commission, 2014), and it is critical in the overall development of individuals and the nation at large. On the other hand, malnutrition remains a major health problem and is responsible for one-third of all infant and child mortality especially in third world countries(Bryce et al., 2005; Muller et al., 2005; UNICEF/WHO/World Bank, 2012; WHO, 2013). Malnutrition is the consumption of dietary nutrient either insufficiently or exclusively (Etim et al., 2017). In most countries, it is often observed that child mortality arises from the synergistic impact of effect of under-nutrition and infection(Black et al., 2008). Children who are severely malnourished are susceptible to impaired cognitive growth and development which consequently affect them later in life as they grow older(Black et al., 2008). Long-term malnutrition among children under five years of age results from poor dietary intake which can adversely lead to dysfunction of the physical and mental health(Victoria et al., 2008; WHO, 2013).

The burden of malnutrition commonly occurs within the African and Asian countries of the world. Evidence-based studies have shown that, of the 162 million children under five years who were stunted, $36 \%$ of them resided in Africa while $56 \%$ were found in Asia(UNICEF/WHO/World Bank, 2012). Victoria et al.(2008) reported that an estimated 60 million underfive children were found to be stunted out of which 11 million were Nigerian children. In Nigeria, the pattern and severity of childhood malnutrition has steadily increased from $11 \%$ in 2003 to $18 \%$ in 2013 for wasting; $24 \%$ in 2003 to $29 \%$ in 2013 for underweight, although there was a decline from $42 \%$ in 2003 to $37 \%$ in 2013 for children who were stunted(National Population Commission, 2013). Malnourished children are more likely to suffer from impaired physical and intellectual growth which makes them less productive during adulthood(Smith et al., 1999). Glewwe et al.(2001) have reported that poor school performance, increased school absenteeism, reduced intellectual achievement, delayed cognitive development and increased disease morbidity and mortality are common effects of malnutrition among under-five children. In low and middle income countries (LMICs), it is estimated that about 10 million children die from treatable and preventable illnesses annually(UNICEF, 2009; Etim, 2016; Etim et al., 2017).

High rates of child mortality in Sub-saharan Africa results from factors such as low intake of calories, high rates of HIV/AIDS, political instability, poor

R. E. Kalu, Federal Medical Center, Yenogoa, Bayelsa State, Nigeria.

K. D. Etim, Department of Public Health, University of Calabar, Calabar, Nigeria. 
implementation of government policies, conflicts among groups, etc. (Etim, 2016). For instance, $50 \%$ of the children of Malawi, Burundi and Madagascar are stunted as a result of poor dietary intake or poor consumption of vital nutrients (UNICEF, 2009). Also, malnutrition accounts for $49 \%$ school absenteeism in $42 \%$ of Nigerian children (Yanusa et al., 2012). Factors such as poverty, failure to breastfeed exclusively, maternal factors such as poor nutrition during pregnancy, lack of appropriate weight gain, illnesses like diarrhea, acute respiratory infection, poor consumption of vitamin supplements or fortified foods, large family size, poor sanitation, lack of education and information about good or adequate nutrition and food insecurity and safety have been identified as factors that affect under-five children's nutritional status(Babatunde et al., 2007; Aliyu et al., 2012; WHO, 2011; Ejemot et al., 2015; Hernel et al., 2015). A lot of studies on malnutrition as it affects the children of Sub-saharan Africa has been carried out. The aim of this study was to carry out a review of the factors which are associated with malnutrition of children in developing countries.

\section{NUTRITIONAL REQUIREMENT FOR INFANCY AND EARLY CHILDHOOD}

A balance between high energy and nutrient content required for growth and development of infants and children in conjunction with regular physical exercise, should constitute childhood nutrition. Therefore, childhood nutrition should be made up of natural, fresh sources of energy and nutrients. The requirements for micronutrients and macronutrients are highly needed during infancy and early childhood than at any other stage of development. Institute of Medicine (2005) has reported that these requirements are triggered by rapid cell division that occurs during growth which requires nutrients, proteins and energy in DNA synthesis and metabolism of calories, protein and fat.

With respect to energy, a $4 \mathrm{~kg}$ infant requires over $100 \mathrm{Kcal} / \mathrm{kg}$ (430 calories/day) while adults require 25 to 30 calories per $\mathrm{kg}$, implying that energy needs during early formative years remain very high (Etim, 2016). Breast milk has been considered to be a significant energy source as it has been shown to reduce the risk of chronic disease conditions such as diabetes, hypertension, allergies and obesity (Etim et al., 2017). Also, breastfeed has been proved to improve cognitive development and decrease the severity of infections (Leung et al., 2005). Equally, water requirement for infants and children is usually higher than that of adults due to the fact that children have a reduced capacity to sweat and have a larger body surface area per unit body weight when compared with adults (Etim et al., 2017). Regarding essential fatty acids, infants require higher fatty acid than adults. The conversion of linolenic and alpha-linotenic acid into longchain fatty acid through elongation and desaturation, plays a vital role in cognitive growth and development in infants (Ascherio and Willet, 1997). Other nutritional requirements include high supply of protein, iron, vitamins $A$ and $D$ and calcium. Also whole cow's milk for one year old children, red meat for six months old babies, green vegetables, cereals, bread, etc., are highly recommended for children (Etim et al., 2017).
FACTORS AFFECTING NUTRITIONAL STATUS OF CHILDREN

Malnutrition is caused by several factors such as poor psychological care, neglect of children, child abuse, stress and trauma (UNICEF, 2007). For instance, mothers with psychological problems may lack the cognitive abilities to recognize that they need to feed their children, thus increasing the risk of under-nutrition in children.

\section{(i) Child factors}

Certain child factors such as sex, age, diseases, breastfeeding and position of child in a household adversely affect the nutritional status of under-five children. An epidemiological study carried out in urbanslum area of Varanasi revealed that $58.3 \%$ of male children had protein energy malnutrition (PEM) while PEM was found in $68.6 \%$ of female children (Baranwal et al., 2010). In the same study, PEM was observed to be higher in $3^{\text {rd }}$ year of life, and lowest during the $2^{\text {nd }}$ year of life. Nyaruhucha et al. (2006), found out in their study that under-nutrition was most prevalent among children aged 24-35 months while children less than a year were less vulnerable to under-nutrition. It has been observed that stunting is strongly associated with sex and weight of children independently (Nyaruhucha et al., 2006).

In Sub-saharan Africa, studies to determine the association between nutritional status of children and birth weight have been reported, but few studies have recorded gender differential in malnutrition among under-five children (Wamani et al., 2007; Hien and Kam, 2008). A study carried out in India reported that children aged 13-24 months were more stunted (81.8\%) and underweight (45.5\%), while wasting (18.2\%) was highest among 37-48 months old children (Kumar et al., 2006). This clearly indicates that children more than one year of age are more likely to have malnutrition than children less than a year. In some cultures especially in Africa, male children are given more preferences than female children because the males will live to carry on with the family name while females will be given out in marriage, thus placing the female child at high nutritional risk. Nyaruhucha et al. (2006) reported that, slightly above one-fourth of male members of a household were first given food before females. Olack et al. (2011) reported that moderate wasting was high in children $(4.1 \%)$ who were between 6-11 months and lowest (1.1\%) in 48-59) months old children. In the same study, more than half of girls $(65.7 \%)$ were more wasted than their boys counterparts. Wasting was significantly higher in girls than in boys of the same age group (Olack et al., 2011). Olack et al. (2011) further reported that certain health conditions such as tuberculosis (TB), diarrhea, measles, etc., can exacerbate malnutrition in children, and a combination of these health problems can weaken the immune system.

\section{(ii) Maternal factors}

Maternal literacy is one of the factors affecting nutritional status of under-five children. According to Asindi et al. 
(1990), children often need primary care for the first 6 years of life from the mothers/caregivers, and the quality of care given by the mothers/caregivers depends largely on the mothers' knowledge of basic health care practices and nutrition. It has also been reported that literate mothers are more likely to delay child bearing at a later age thereby lowering infant mortality (Chen, 1986). Sufiyan et al. (2012), found that children of uneducated mothers are at risk of stunting. In another study, Ali et al. (2005) found out that stunting was $40.8 \%$ higher among children of illiterate mothers, underweight (57.9\%) highest among children of mothers who had attained at least primary education and wasting (33.3\%) was common among children of mothers who had tertiary education. Glewwe (1999) highlighted that education can affect the child's health through direct transfer of health information from one generation to another; through the ability to promptly detect illness and treatment administered and through educated mothers who tend to be receptive to orthodox medication than uneducated mothers. The above links have been established because educated women are more likely to marry men with higher income, live in better neighbourhood, get higher paid jobs which directly or indirectly influence child survival and health (Desai and Alva, 1998).

In developing countries, women have been recognized for playing dual roles as primary caregivers to their children and generators of household income. Glick and Sahn (2001) argued that the more women participate in the labour workforce, the less attention they pay to household responsibilities especially as it relates to the welfare of children, thereby placing younger children at risk of malnutrition. Abbir et al. (2006) stated that children's nutrition and health status can be negatively affected by their mothers' occupation outside child rearing. This is so because time constraints may prevent working-class mothers from providing the need care to their children. Several studies have indicated that young maternal age is associated with high prevalence of malnutrition, while children of older women are less likely to suffer from malnutrition (Nyaruhucha et al., 2006). A study carried out in Tanzania reported that children of older mothers are less likely to be malnourished than those of young mothers (Nyaruhucha et al., 2006).

\section{SOCIO-ECONOMIC/HOUSEHOLD FACTORS}

\section{(i) Poverty}

It is general knowledge that malnutrition is a condition that is associated with poverty since it comes with hunger and lack of food at the right quantity and quality. Malnutrition could also come as a result of loss of appetite, and this may be common among terminally ill people such as HIVIAIDS, cancer and failed organ patients, kwashiorkor people and elderly people (Etim, 2016). Etim (2016) has reported that, in Sub-saharan Africa, the proportion of people affected by extreme poverty has nearly doubled from 164 million in 1982 to 313 million as of 2002 in the last two decades. It is estimated that over $70 \%$ of Nigerians live below poverty line of $\$ 1$ per day with Northern Nigeria being the worst hit area (Olanrewaja, 2011). Olanrewaja (2011) has attributed poverty in Nigeria to be precipitated by such factors as corruption, unfavourable government policies, poor investment in education, etc.

\section{(ii) Family size}

According to Chaudhury (2009), children nutritional status can be affected by increase in family size due to decrease in per capita income. That means that increase in the number of children in a household decreases the food allocated to each child which consequently affects children nutritional status. Increase in household size also facilitates fertility decision between couples. In such situations, large family size may adversely affect the nutritional status of children and household members thereby promoting poor dietary practices especially in poorer households (Chaudhury, 2009).

\section{(iii) Household income and expenditure}

A household income level is clearly determined by the rate of expenditure on food. Expenditure on food is likely to increase where there is improvement of household income thereby increasing the rate of caloric and protein intake among children and members of the household (Reutlinger and Selowsky, 1976). On the other hand, poor household income can lead to less expenditure on food and low nutrient/dietary intake. Chaudhury (2009) pointed out that a synergistic relationship exists between dietary adequacy, dietary intake and per capita expenditure.

\section{(iv) Household food security and insecurity}

Certain factors such as location of the house, family income level and household size can significantly influence household food security. Food security is the sufficient availability, nutritionally adequate and safety of food consumed in a way that is socially acceptable (Oquntin, 2010). On the other hand, food insecurity occurs when the ability to acquire safe, nutritionally adequate food is limited or uncertain (Oquntin, 2010). It has been observed that, in most developing countries, the dietary practice in populations experiencing food insecurity tends to meet their energy requirements but do not provide sufficient nutrients to optimize health and prevent infection. Hence, it can be inferred that overnutrition and under-nutrition are strongly associated with food insecurity (Babatunde et al., 2007; Awoyemi et al., 2012). Factors such as poor academic performance, physical and mental ill-health, psycho-social problem and anaemia related to iron deficiency are consequences of food insecurity in children (Food and Agricultural Organization, 2008; Akinyele, 2009).

\section{(v) Educational status}

Parent education is a strong determinant of children nutritional status. That means that higher educational status of parents is associated with better child rearing and care practices. According to Chaudhury (1983), children whose parents are educated up to the tertiary level are more likely to have a nutritious diet irrespective 
of income level due to their increased level of knowledge on basic child nutrition. On the other hand, parents with higher educational attainment may promote values to the detriment of children's health (Chaudhury, 1983). For instance, women who work outside their homes are less likely to breastfeed their babies consistently and exclusively; and these women are more likely to practice early weaning (Chaudhury, 1983).

\section{(vi) Lack of access to food}

Food insecurity usually results from the inability of individuals to purchase enough food and not because of lack of food itself. Etim (2016) reported that poor road networks, scarcity of food in markets and poor family income levels are factors that promote food insecurity among the disadvantaged populations. Countries sometimes depend on the importation of food especially when there is food scarcity in their own countries (Etim, 2016). Etim (2016) reports that many people especially the poorer populations, are affected by fluctuations in food prices. In situations when the price of food is low, farmers may produce less food products which may not be proportionate to the demand by consumers, and as such may result in food scarcity in markets (Etim, 2016).

\section{(vii) Socio-demographic factors}

In Sub-saharan Africa, several demographic trends inhibit the amelioration of malnutrition in children (Etim, 2016). For instance, rapid population growth has been identified as a major demographic factor exacerbating malnutrition in under-five children (Etim, 2016). It is often observed that higher fertility is highly exhibited by the poor who are more likely to be malnourished than people who belong to the wealthy quintiles (Etim, 2016). However, the poor urban and rural populations suffer most from poor nutrition (Etim, 2016).

\section{(viii) Environmental factors}

In sub-tropical and tropical regions, $95 \%$ of all malnourished individuals live in relatively stable climate. Thus, climate change is a significant factor to be considered when ensuring substantial availability of food (food security) (Climate Change, 2007). Latest report has shown that temperature increase in the sub-tropics and tropics are very likely (climate change) Climate Change, 2007). A United Nations study carried out in over 40 developing countries showed that climate change directly or indirectly influence the decline in agricultural production and may as a result increase the number of people suffering from hunger each year (Action Against Hunger, 2012). Even a slight change in temperature can affect the weather conditions (Climate Change, 2007). Agricultural production and good nutrition are highly affected by the impact of these events. For instance, during the Central Asian drought, there was about $50 \%$ reduction in wheat production and $80 \%$ loss of livestock products (Battisti, 2008). In Subsaharan Africa, extreme weather conditions such as drought, can diminish productivity of many crop species thereby exacerbating the impact of malnutrition (Battisti, 2008).
Poor children often reside in urban slums or very rural areas where there is absolute lack of basic amenities such as water supply and other sanitation facilities which lead to contamination of water bodies which in turn, can cause diarrhoea (Black et al., 2011). Diarrhoea promotes wasting and prevents children from getting enough nutritious food.

\section{(ix) Other factors}

In the face of conflicts and crisis within countries, food security and access to food are significantly compromised. Conflicts often lead to annihilation of farmlands and farm businesses, low food productivity and limited level of food distribution internally. As a result, people are often susceptible to starvation, illness and diseases than may arise from food insecurity. A recent survey carried out in Afghanistan revealed that water-related hardship was a major determinant of health and nutritional status of children under five years of age (Mashal et al., 2008).

\section{CONCLUSION}

Several researches have been carried out to investigate malnutrition-dependent factors in different parts of the world especially developing countries (Mashal et al., 2008; Black et al., 2011; Action Against Hunger, 2012; Etim et al., 2017). Some authors have associated child factors such as sex, age, diseases and child position in a household with malnutrition (Baranwal et al., 2010; Nyaruhucha et al., 2006). In Sub-saharan Africa association has been established between nutritional status of children and birth weight (Wamani et al., 2007; Hien and Kam, 2008). Some authors point to maternal literacy as having a significant impact on the nutrition of children (Sufiyan et al., 2012; National Population Commission, 2013). A good number of the researches have pointed to socio-economic/household factors which influence malnutrition. For example, poverty (Olanrewaja, 2011; Etim, 2016; Etim et al., 2017), family size (Chaudhury et al., 2009), household income and expenditure (Reutlinger and Selowsky, 1976), household food security and insecurity (Food and Agricultural Organization, 2008; Akinyele, 2009; Oquntin, 2010; Awoyemi et al., 2012; functional education (Chaudhury, 1983), lack of access to food (Etim, 2016), socio-demographic factors (Etim, 2016), environmental factors (Climate Change, 2007) and wars and crisis in a country (Mashal et al., 2008), have all been recognized as malnutrition dependent factors. In conclusion, governments of developing countries and the global community should work together to remove these factors.

\section{REFERENCES}

Abbir, C. P., Gujal, S. and Gopaldas, L., 2006. The impact of maternal work status on the nutrition and health status of children @ archive. Unu.edu/unapress/food/8f13 le/f13IE03.htm.

Action Against Hunger., 2012. Underlying causes of malnutrition. Retrieved February 13, 2012 at www.acctioncontrolafain.cc. 
Akinyele, I. O., 2009. Ensuring food and nutrition security in rural Nigeria: An assessment of the challenges, information needs, and analytical capacity. IFPRI - NSSP Background paper No. NSCP007.

Ali, S. S., Haider, S. S., Karim, N. and Billo, A. G., 2005. Association of literacy of mothers with malnutrition among children under three years of age in rural area of District Malir, Karachi. Journal of Pakistan Medical Association. 2(3):13-19.

Aliyu, A. A., Oguntunde, O. O., Dahiru, T. and Raji, T., 2012. Prevalent and determinants of malnutrition among pre-school children in Northern Nigeria. Pakistan Journal of Nutrition.11(11):1092-1095.

Ascherio, A. and Willet, W. C., 1997. Health effects of trans fatty acids. American Journal of Nutrition. 66(4): 10065-10105.

Asindi, A. A., Ibia, E. O. and Udo, J. J., 1990. Mortality pattern among Nigerian children in the 1980s. Journal of Tropical Medicine and Hygiene. 94:152-5.

Awoyemi, T. T., Odozi, J. C. and Ogunmiyi, A. A., 2012. Environmental and socio-economic correlates of child malnutrition in Iseyin area of Oyo State, Nigeria. Food and Public Health. 2(4):92-98.

Babatunde, R. O., Omotesho, O. A. and Sholotan, O. S., 2007. Socio-economic characteristics and food security status of farming households in Kwara State, North-Central Nigeria. Pakistan Journal of Nutrition. 6:49-58.

Baranwal, K., Gupta, V. M., Mishra, R. N., Prakashs, N. and Pandey, O. N., 2010. Factors influencing the nutritional status of under five (1-5years) children in urban-slum area of Varanasi. Indian Association of Preventive and Social Medicine, Uttar Predesh and Uttarakhand State Chapter.

Battisti, D. S., 2008. Climate change in developing countries. University of Washington, Seattle. Retrieved from cses.washington.edu/dp/ pdf/wacciachadapt654.pdf.

Black, B., Burke, H. and Breiman, R. F., 2011. Nutritional status of under-five children living in an informal urban settlement in Nairobi, Kenya. Journal of Health Population and Nutrition. 29(4):357-363.

Black, R. E., Allen, L. H., Bhutta, Z. A., Caulfield, L. E., de Onis, M., Ezzati, M., Mathers, C. and Rivera, J., 2008. Maternal and child undernutrition: Global and regional exposures and health consequences. Lancet. 19; 371(9608):243-60.

Bryce, J., Boschi-Pinto, C., Shinbuya, K. and Black, R. E., 2005. WHO estimates of the causes of death in children. Lancet. 1; 365 (9465):1147-52.
Chaudhury, M. S. I., Akhter, N., Haque, M., Aziz, R. and Nahar, N., 2009. Serum total protein and albumin levels in different grades of protein energy malnutrition. Journal of Bangladesh Society of Physiologist. 3(11):234-245.

Chaudhury, R. H., 1983. Effects of mothers' work on child care, dietary intake, and dietary adequacy of pre-school children. International Food and Nutrition Program, Massachusetts Institute of Technology, Cambridge.

Chen, L. C., 1986. Primary health care in developing countries: Overcoming operational, technical and social barriers. Lancet. 2:1260-5.

Climate Change, 2007. Synthesis Report. Intergovernmental Panel on Climate Change. 12-17 November. Retrieved from www.intergovernmentalpanelonclimatechange. org.

Desai, S. and Alva, S., 1998. Maternal education and child health: Is there a strong causal relationship? Demography. 35(1): 71-81.

Ejemot-Nwadiaro, R. I., Ehiri, J. E., Arikpo, D., Meremikwu, M. M. and Critchley, M., 2015. Handwashing promotion for preventing diarrhea. Cochrane Database of Systematic Reviews. John Wiley and Sons Ltd., Oxford, Retrieved from http://www.thecockranelibrary. com.

Etim, K. D., 2016. Nutritional status of children under five years in Ekureku community, Abi L. G. A. of Cross River State, Nigeria. M.Sc. Thesis submitted to Graduate School, University of Calabar, Calabar, Nigeria.

Etim, K. D., Ejemot-Nwadiaro, R. I. and Kalu, R. E., 2017. A study of malnutrition-dependent factors among under-five children in Ekureku community, Abi Local Government Area of Cross River State, Nigeria. British Journal of Medicine and Medical Research. 21(8):1-10.

Food and Agricultural Organization, 2008. The state of food insecurity in the world. Food and Agricultural Organization, Rome.

Glewwe, P., 1999. Why does mother's schooling raise child health in developing countries? Evidence from Morocco. Journal of Human Resources. 34(1):124-15.

Glewwe, P., Jacoby, H. G. and King, E. M., 2001. Early childhood nutrition and academic achievement: A longitudinal analysis. Journal of Public Economics. 81(3):345-368.

Glick, P. and Sahn, D. E., 2001. Maternal labour supply and child nutrition in West Africa. Oxford Bulletin of Economics and Statistics. 60(3): 1468-0084. 
Hernel, C., Enne, J., Omer, K., Ayara, N., Yarima, Y., Cokcroft, A. and Anderson, N., 2015. Childhood Malnutrition is associated with maternal care during pregnancy and childbirth: A crosssectional study in Bauchi and Cross River States, Nigeria. Journal of Public Health Research. 4(1):139-148.

Hien, N. N. and Kam, S., 2008. Nutritional status and the characteristics related to malnutrition in children under five years of age in Ngbean, Vietnam. Journal of Preventive Medicine and Public Health. 41(4):232-240.

Institute of Medicine, 2005. Dietary Reference Intakes for Energy, Carbohydrate, Fiber, Fat, Fatty Acids, Cholesterol, Protein and Amino Acids (Macronutrients). National Academic Press, Washington D. C.

Kumar, D., Goel, N. K., Mittal, P. C. and Misra, F., 2006. Influence of infant-feeding practices on nutritional status of under-five children. Indian Journal of Pediatrics. 73(50: 417-21.

Leung, A. K. and Sauve, R. S., 2005. Breast is best for babies. Journal of the National Medical Association. 97:1010-1019.

Mashal, T., Takano, T., Kakamura, K., Kizuki, M., Harmat, S., Waranbe, M. and Seinok, L., 2008. Factors associated with the health and nutrition of children under 5 years of age in family behavior related to women and past experience of war related hardships. BMC Public Health. 8(301):1471-2458.

Muller, O. and Krawinkel, M., 2005. Malnutrition and Health in developing countries. Canadian Medical Association Journal. 173(3):279-86.

National Population Commission (NPC) [Nigeria] and ICF International, 2014. Nigeria Demographic and Health Survey 2013. Abuja, Nigeria, and Rockville, Maryland, USA, NPC and ICF International.

National Population Commission (NPC) [Nigeria] and ICF International, 2013. Nigerian Demographic and Health Survey, Abuja, Nigeria and Rockville, Maryland, USA.

Nyaruhucha, C. M., Msuya, J. M., Mamiro, P. S. and Kerengi, A. J., 2006. Nutritional status and feeding practices of under-five children in Samanjiro District, Tanzania. Tanzania Health Research Bulletin. 8(30:162-167.

Olack, B., Burke, H., Cosmas, L., Bamrah, S., Dooling, K., Feikin, D. R., Talley, L. E. and Breiman, R. F., 2011. Nutritional status of under-five children living in an informal urban settlement in Nairobi, Kenya. Journal of Health Population and Nutrition. 29(4):357-363.
Olanrewaja, S., 2011. Nigeria still wallowing in poverty. The Nigerian Tribune. Retrieved from www.9jabook.com/forum/ topics/ nigeria-stillwallowing-in-poverty.

Oquntin, T. A., 2010. Maternal socio-demographic factors influencing initiation and exclusivity of breastfeeding in a Nigerian semi-urban setting. Child Health Journal.14(3):459-65.

Reutlinger, S. and Selowsky, M., 1976. Malnutrition and poverty: Magnitude and policy options. World Bank Staff Occasional Papers, No. 23, John Hopkins University Press, Baltimore and London.

Smith, L. C. and Haddad, L., 1999. Explaining child malnutrition in developing countries: A crosscountry analysis. IFPRI FCND Discussion Paper No. 60, IFPRI, Washington, D.C. USA.

Sufiyan, M. B., Bashir, S. S. and Umar, A. A., 2012. Effect of maternal literacy on nutritional status of children under 5 years of age in the BabbanDodo community of Zaria city, Northwest Nigeria. Annals of Nigerian Medicine. 6(2):6164.

UNICEF, 2009. The state of the world's children. Special edition: Celebrating 20 years of the convention on the rights of the child. New York, United Nations Children's Fund 92.

UNICEF/WHO/World Bank, 2012. Joint child malnutrition estimates level and trends. Retrieved from www.who.int/nutgrowthdb/ estimate2012/enn/.

Victoria, C. G., Adair, L., Fall, C., Hallal, P. C., Martorell, R., Richter, L. and Sachdev, H. S., 2008. Maternal and child under nutrition: Consequences for adult health and human capital. Lancet. 26; 371(9609): 340-57.

Wamani, H., Astrom, A. N., Peterson, S., Tumwine, J. K. and Tylleskar, T., 2007. Boys are more stunted than girls in Sub-saharan Africa: A meta-analysis of 16 demographic and health surveys. BMC Pediatrics. 7:17.

WHO, 2011. Global Database on Childhood Growth and Malnutrition. Retrieved from www.who.int/nutgrowthdb.

WHO, 2013. Updates on the management of severe acute malnutrition in infants and children. ISBN: 978921506328, 111pp.

Yunusa, I., Gumel, A. H. and Adegbusi, K. A. S., 2012. School feeding program in Nigeria: A vehicle for nourishment of pupils. The African symposium: An online Journal of the African Educational Research Network, volume 12, No. 2. Retrieved at http://www.ncsu.ed/ aern/TAS12.2/TAS12.2 Yunusa.pdf. 
